\title{
1 Size distribution of absorbing and fluorescing DOM in Beaufort Sea,
}

\section{Canada Basin}

3 Zhiyuan $\mathrm{Gao}^{1}$, Céline Guéguen ${ }^{2}$

$4{ }^{1}$ Environmental and Life Sciences Graduate program, Trent University, Peterborough, ON, K9L 0G2, Canada

$5{ }^{2}$ Chemistry Department, Trent University, Peterborough, ON, K9L 0G2, Canada

6 Correspondence to: Céline Guéguen (celinegueguen@trentu.ca)

7 Abstract. The molecular weight (MW) of dissolved organic matter (DOM) is considered as an important factor affecting the

8 bioavailability of organic matter and associated chemical species. Colored DOM (CDOM) MW distribution was determined,

9 for the first time, in the Beaufort Sea (Canada Basin) by asymmetrical flow field-flow fractionation (AF4) coupled with

10 online diode array ultra violet-visible photometer and offline fluorescence detectors. The apparent MW ranged from 1.07

$11 \mathrm{kDa}$ to $1.45 \mathrm{kDa}$, congruent with previous studies using high performance size exclusion chromatography and tangential

12 flow filtration. Interestingly, a minimum in MW was associated with the Pacific Summer Waters (PSW), while higher MW

13 was associated with the Pacific Winter Waters (PWW). The Arctic Intermediate Waters (AIW) did not show any significant

14 change in MW and fluorescence intensities distribution between stations, suggesting homogeneous DOM composition in

15 deep waters. Three fluorescence components including two humic-like components and one protein-like component were

16 PARAFAC-validated. With the increase of MW, protein-like fluorescence component became more dominant while the

17 majority remained as marine/microbially derived humic-like components. Overall, it is concluded that water mass origin

18 influenced DOM MW distribution in the Arctic Ocean.

19

20 Keywords. DOM, Asymmetrical flow field-flow fractionation (AF4), Molecular weight (MW), PARAFAC-EEM

(C) 2016. This manuscript version is made available under the Elsevier user license

http://www.elsevier.com/open-access/userlicense/1.0/ 
Dissolved organic matter (DOM), usually measured as dissolved organic carbon (DOC), is a major carbon pool in aquatic systems (Amon and Benner, 1994; Benner et al., 1992; Jiao et al., 2010). DOM serves as a source of food for microorganisms (Cole et al., 2006), contributing to the food web and energy transport (Baylor and Sutcliffe Jr, 1963). DOM also plays an important role in regulating the speciation and distribution of trace metals such as $\mathrm{Cu}, \mathrm{Hg}, \mathrm{Fe}$ and $\mathrm{Zn}$ (Hirose, 2007; De Schamphelaere et al., 2004; Yamashita and Jaffé, 2008). Previous studies showed that increased Cu-binding affinity was observed with increasing DOM molecular weight (MW) in natural waters (Midorikawa and Tanoue, 1998; Wu and Tanoue, 2001). High MW DOM complexation was favoured by metals with high binding strength while low MW DOM was preferentially bound by weak binding strength metals (Wu et al., 2004). Besides affecting metal binding affinity, DOM MW could influence uptake by microorganisms (Guo and Santschi, 2007; Sun et al., 1997). For example, high MW oceanic DOM was favoured by bacterial utilization (Amon and Benner, 1996), boosting growth rates of some bacterial group and algae (Tulonen et al., 1992).

The heterogeneous nature of DOM requires the use of complementary analytical techniques. The absorbance and

34 fluorescence properties of DOM have been increasingly used in differentiating allochthonous and autochthonous DOM sources (Stedmon et al., 2003) and tracing riverine supply into the ocean system (Fichot et al., 2013; Fichot and Benner, 2012; Guéguen et al., 2011, 2012a; Nelson et al., 2010; Stedmon et al., 2011). The ultraviolet-visible absorbance properties of chromophoric dissolved organic matter (CDOM) have been used as molecular size and aromaticity proxies (Guéguen and

38 Cuss, 2011; Helms et al., 2008). emission matrix (EEM; Coble, 1996) technique coupled to parallel factor analysis 39 (PARAFAC; Murphy et al., 2008) have been used to facilitate the identification and quantification of independent 40 fluorescent classes such as protein-like, microbially derived and terrestrial humic-like in marine studies (e.g. Dainard and 41 Guéguen, 2013; Guo et al., 2011; Murphy et al., 2008). Asymmetrical flow field-flow fractionation (AF4) is a chromatographic-like method that has been recently applied to investigate the sources and dynamics of DOM in aquatic systems (Boehme and Wells, 2006; Guéguen and Cuss, 2011; Lin et al., 2016; Stolpe et al., 2010, 2014). For example, Lin et al., (2016) showed that the 1-10kDa CDOM fraction was influenced by terrestrial input. Stolpe et al., (2014) concluded that 
the small MW DOM (2-3nm) in surface northern Gulf of Mexico originated from terrestrial sources whereas the larger MW DOM (>6 nm) was protein-rich and freshly produced.

The Arctic regions are undergoing rapid changes in air temperatures, river discharge, sea ice extent and permafrost integrity (Frey and McClelland, 2009; Overland and Wang, 2013; Peterson et al., 2002; Schuur et al., 2009; Shimada et al., 2006). Continued climate change will likely have profound effect on carbon cycle. Documenting the composition and distribution of DOM (i.e. MW and optical properties) could provide valuable insights into the biogeochemical carbon cycle.

In this study, DOM samples were collected at four sites and five water masses in Beaufort Sea: Arctic Surface Water (ASW), Pacific Summer Water (PSW), Pacific Winter Water (PWW) and Arctic Intermediate Waters (AIW) including Fram Strait Branch (FSB) waters and Barents Sea Branch (BSB) water (Carmack et al., 2015; McLaughlin et al., 2011; 2004; Rudels et al., 2012; Woodgate et al., 2005). The DOM MW distribution in the Arctic Ocean was assessed, for the first time, using asymmetrical flow field-flow fractionation (AF4) coupled with online diode array ultra-violet/visible photometer and offline fluorescence detectors.

\section{Methods}

\subsection{Sampling Sites}

A total of 88 samples, including 20 samples for MW analysis, were collected at 4 sites (CB28b, CB29, CB50 and CB51; Fig. 1) in Beaufort Sea in September 2014 as part of the Joint Ocean Ice Studies cruise. Water samples were collected at depths ranging from $5 \mathrm{~m}$ to $1000 \mathrm{~m}$ at each site using Niskin bottles mounted on a rosette together with a conductivity temperature - depth profiler and immediately filtered using pre-combusted $\left(450{ }^{\circ} \mathrm{C}\right.$ for $\left.4 \mathrm{~h}\right) 0.7 \mu \mathrm{m}$ glass fiber filters (GF/F,

Whatman) and stored in the dark at $4{ }^{\circ} \mathrm{C}$ in pre-combusted amber glass vials until measurement. The AF4 based MW distribution was carried out on samples collected at 10 m, sub-chlorophyll maximum (i.e. 50 - 68 m), salinity 33.1 (i.e. 148 $161 \mathrm{~m}$ ) and temperature maximum (i.e. $414-433 \mathrm{~m}$ ) and $1000 \mathrm{~m}$ at each site (Fig. 1). High-resolution vertical profiles of humic-like fluorescent DOM (FDOM), primarily derived from terrestrial sources, were also acquired using a WET Labs probe (WETStar Ex/Em 370/460 nm) at each site. 


\subsection{Asymmetrical Flow Field-Flow Fractionation}

MW distribution was assessed using an asymmetrical flow field-flow fractionation (AF4) system within 10 days of collection to avoid MW alteration (Guéguen and Cuss, 2011). AF4 is carried out using an AF2000 Focus fractionation system (Postnova Analytics, Landsberg, Germany) which includes two PN1130 HPLC pumps to control the axial and focus flows, a PN1610 syringe pump to control the crossflow rate, and a PN7505 degasser to remove gas from the carrier solution prior to introduction to the pumps (Guéguen and Cuss, 2011). Absorbance scan was recorded from $270 \mathrm{~nm}$ to $700 \mathrm{~nm}$, using an on-line diode array ultra-violet/visible photometer (Shimadzu SPD-M20A). The fractionation system is equipped with a 300 Da polyethersulfone membrane (Guéguen and Cuss, 2011; Guéguen et al., 2013; Zhou and Guo, 2015). It should be noted that DOM smaller than $300 \mathrm{Da}$ will not retained on the AF4 membrane and thus not measured. The $\mathrm{pH}$ and conductivity of the $\mathrm{NaCl}$ carrier solution matched that of the Arctic samples $(20 \mathrm{mS} / \mathrm{cm}, \mathrm{pH} 7.9)$ to preserve the native chemical environment of DOM.

The AF4 system was operated under the following conditions: detector flow rate at $0.35 \mathrm{~mL} / \mathrm{min}$, focusing at 0.15 $\mathrm{mL} / \mathrm{min}$ focus flow rate for $7 \mathrm{~min}$, elution at $2.20 \mathrm{~mL} / \mathrm{min}$ cross flow rate for $13 \mathrm{~min}$. MQ blank were performed under the same operating conditions between each DOM sample to avoid any cross contamination. In order to get accurate MW distribution, the AF4 system was calibrated at $254 \mathrm{~nm}$ using a log-log calibration based on four macromolecules (laser grade rhodamine B (479 Da), bromophenol blue (692 Da), cytochrome C (12,400 Da) and lysozyme (14,300 Da) twice a day, at the beginning and the end of each day (Guéguen and Cuss, 2011). The simultaneous multi wavelength measurements of the online absorbance detector allow us to accurately determine of each of the four macromolecules in a single injection. The retention time at $254 \mathrm{~nm}$ was used to estimate the CDOM MW at peak maximum intensity (Guéguen and Cuss, 2011; Lin et al., 2016; Stolpe et al., 2010, 2014). For example, a typical calibration recorded at $254 \mathrm{~nm}$ was $\log ($ Time $)=(0.1634 \pm$ $0.0086) * \log (\mathrm{MW})+(0.4831 \pm 0.0228)\left(\mathrm{r}^{2}=0.999\right)$. The smallest and largest macromolecules, rhodamine-B and lysozyme, respectively, were eluted at $8.680 \pm 0.165(\mathrm{n}=10)$ and $14.759 \pm 0.503 \mathrm{~min}(\mathrm{n}=10)$, respectively. It can be noted that the retention time (i.e. MW) of the Beaufort samples was $4.8 \%$ higher $(\mathrm{n}=20)$ at $350 \mathrm{~nm}$ than at $254 \mathrm{~nm}$, confirming the higher MW of aromatic CDOM (Cuss and Guéguen, 2013). A typical chromatogram (Fig. 2) showed a very sharp peak representing the void peak with unfocused and small MW materials and a smooth peak containing the focused and eluted 
material. The AF4 fractions corresponding to the material eluted after the void peak (Fig. 2) were collected using a fraction collector (Varian ProStar 701).

In terms of repeatability, MW of bromophenol blue sodium salt (Sigma-Aldrich) was measured daily $(\mathrm{n}=10)$ and was within 6\% of the recommended MW (669 Da). The relative standard deviation of MW of Suwannee River natural organic matter $(\mathrm{n}=5)$ was $3 \%$ (or $85 \mathrm{Da})$. Similar precision was reported in earlier work (Guéguen and Cuss, 2011).

\subsection{Chromophoric dissolved organic matter (CDOM) and Fluorescent DOM (FDOM)}

Chromophoric dissolved organic matter (CDOM) samples were allowed to warm to room temperature before analyzing on a Shimadzu UV 2550 spectrophotometer. Milli-Q water was measured between each samples to avoid carry-over. A slit width of $0.5 \mathrm{~nm}$ was applied, with an absorbance acquisition interval of $1 \mathrm{~nm}$. The measured absorbance at wavelength $\lambda$ was converted to absorption coefficient a $\left(\mathrm{m}^{-1}\right)$ as following Eq (1):

$$
a_{\lambda}=2.303 A_{\lambda} / l
$$

where $a_{\lambda}$ is the absorption coefficient at wavelength $\lambda, A_{\lambda}$ is the instrumental absorbance signal, 1 is the path-length of the optical cell in meters (i.e. $10 \mathrm{~cm})$. Absorbance coefficient at $254 \mathrm{~nm}\left(\mathrm{a}_{254}\right)$ and $355 \mathrm{~nm}\left(\mathrm{a}_{355}\right)$ were used as indicator for CDOM concentration in natural samples (Chen et al., 2004; Dainard and Guéguen, 2013; Granskog et al., 2007; Penru et al., 2013).

Three dimensional excitation-emission fluorescence matrices (EEMs) were generated by measuring fluorescence intensity across excitation wavelengths ranging from 250 to $500 \mathrm{~nm}$ and emission wavelengths ranging from 300 to $600 \mathrm{~nm}$ through successive scans with a Fluoromax-4 Jobin Yvon spectrofluorometer. Excitation and emission slit widths were set to $5 \mathrm{~nm}$. Blank Milli-Q EEMs were measured daily to correct background and scatter peak. Before loading samples, a cuvette was rinsed to avoid cross contamination and scanned at excitation $270 \mathrm{~nm}$ and emission $280-500 \mathrm{~nm}$ for confirmation. All EEMs were normalized to Raman units (R.U.) by dividing the signal at all Ex/Em pairs by the integrated area under the Raman water peak at excitation $350 \mathrm{~nm}$ using a daily acquired Milli-Q blank EEM (Lawaetz and Stedmon, 2009). Absorption spectra were obtained for all natural seawater samples to make sure the intensity were within the linear range $\left(A_{250}<0.05\right)$. 
121 DOMFluor (Stedmon and Bro, 2008) and DrEEM toolboxes (Murphy et al., 2013). The model was constrained to

122 nonnegative values and run for three to ten components. The appropriate number of components was determined by split-

123 half and Tucker congruence coefficient analyses. Percent fluorescence was calculated as follows:

$$
\mathrm{C} 1 \%=\frac{C 1}{(C 1+C 2+C 3)}
$$

\section{Results and Discussion}

\subsection{Hydrographical parameters}

Five main water masses were found based on the temperature/salinity (T/Sp) diagram (Fig. 3A): Arctic surface waters

129 (ASW) in the top $50 \mathrm{~m}\left(\mathrm{Sp}<30\right.$ and $\left.-1.5^{\circ} \mathrm{C}<\mathrm{T}<-0.5^{\circ} \mathrm{C}\right)$ were influenced by river runoff (Cory et al., 2007; Pegau, 2002;

130 Walker et al., 2009), primary production (Fouilland et al., 2007; Hill and Cota, 2005), sea ice formation and melt

131 (Logvinova et al., 2016; Walker et al., 2009), and photobleaching (Bélanger et al., 2006); Pacific summer waters (PSW, $30<$

$132 \mathrm{Sp}<32)$ were characterized by a temperature maximum $\left(\mathrm{T} \sim-0.8^{\circ} \mathrm{C}\right.$; Steele et al., 2004); Pacific winter water $(\mathrm{PWW}, \mathrm{Sp} \sim$

133 33.1) was characterized by a temperature minimum $\left(\mathrm{T} \sim-1.4^{\circ} \mathrm{C}\right.$; McLaughlin et al., 2004) and a terrestrial humic-like

134 maximum (Fig. 3B) (Guéguen et al., 2012b); Deeper layers (> $400 \mathrm{~m}$ ) were dominated by Atlantic-derived Arctic

135 intermediate water (AIW). A temperature maximum near 400 m characterized Fram Strait Branch waters (FSB; Sp 34.8, T

$136 \sim 0.6{ }^{\circ} \mathrm{C}$ ) while lower temperature characterizes the Barents Sea Branch waters $\left(\mathrm{BSB} ; \mathrm{Sp} \sim 34.8, \mathrm{~T} \sim 0{ }^{\circ} \mathrm{C}\right)(\mathrm{McLaughlin}$ et

137 al., 2004; Woodgate et al., 2005).

\section{3.2 Molecular weight depth distribution}

Natural marine CDOM MW ranged from $1.07 \mathrm{kDa}$ to $1.45 \mathrm{kDa}$ (Fig. 4), congruent with previous studies on DOM MW

141 using AF4, high performance size exclusion chromatography and tangential flow filtration (Beckett et al., 1992; Everett et

142 al., 1999; Guéguen and Cuss, 2011; Huguet et al., 2010; Landry and Tremblay, 2012; Penru et al., 2013; Stolpe et al., 2010). 
143 For example, colloidal DOM MW averaged $1.4 \pm 0.4 \mathrm{kDa}$ in Northern Gulf of Mexico (Stolpe et al., 2010). Higher MWs

144 (1.62-2.52 kDa) were reported for colloidal DOM in Chukchi Sea (Lin et al., 2016). The average MW reported in Beaufort

145 Sea agreed with values reported for fulvic acids (Beckett et al., 1987; Guéguen and Cuss, 2011), confirming that fulvic acids

146 are good proxy for marine DOM (Tipping et al., 2015).

Average CDOM MW $(1.37 \pm 0.01 \mathrm{kDa})$ in ASW was remarkably consistent across the study area. This contrasts with

148 the halocline complex and deeper layers where significant MW differences were found (Fig. 4). Compared to ASW, the

149 CDOM MW in PSW was lower, likely due to the influence of sea ice melt waters rich in low MW DOM (Logvinova et al.,

150 2016). CDOM MW increased again in PWW, which resulted from the interactions with C-rich shelf bottom sediment

151 (Moore et al., 1983) remobilizing high MW DOM (Skoog et al., 1996). Below the halocline complex, lower MW CDOM

$152(\sim 1.21 \mathrm{kDa})$ was found with the saline Atlantic waters. The BSB MW was relatively consistent $(1.27 \pm 0.06 \mathrm{kDa})$,

153 confirming the CDOM homogeneity in deeper layer.

\subsection{Optical properties}

The $\mathrm{a}_{254}$ and $\mathrm{a}_{355}$ values (Fig. 5A-B) compared well with previous Arctic studies (Dainard and Guéguen, 2013; Spencer

157 et al., 2009). Relatively low $\mathrm{a}_{254}$ and $\mathrm{a}_{355}$ values (2.444 and $0.2014 \mathrm{~m}^{-1}$, respectively) were found in ASW likely due to photobleaching (Guéguen et al., 2016; Logvinova et al., 2015) and/or sea ice melt (Logvinova et al., 2015) in surface waters.

159 Similar trends were previously observed (Dainard and Guéguen, 2013; Stedmon et al., 2011). The PSW-PWW waters were 160 characterized by high CDOM values (Fig. 5A-B), congruent with previous studies. As proxy for molecular size and 161 aromaticity (Guéguen and Cuss, 2011; Helms et al., 2008), $\mathrm{S}_{275-295}$ ranged from 0.018 to $0.033 \mathrm{~nm}^{-1}$ (Fig. 5C), congruent

162 with previous Arctic DOM studies (Fichot et al., 2013). Although $S_{275-295}$ was not significantly correlated with AF4-based

163 MW in this study, the increase in $\mathrm{S}_{275-295}$ (i.e. decrease in MW) from PSW to deeper waters was consistent with the overall 164 vertical decrease in AF4-based MW (Fig. 4).

165 Three fluorescent components (Fig. 6) were PARAFAC-validated and reported in previous studies (Dainard and 166 Guéguen, 2013; Kowalczuk et al., 2009; McIntyre and Guéguen, 2013; Singh et al., 2010; Stedmon and Markager, 2005;

167 Walker et al., 2009). Component $\mathrm{C} 1$ displayed a maximum excitation wavelength at $305 \mathrm{~nm}$ and emission wavelength at 410 
168

169

170

171

172

173

174

175

176

177

$\mathrm{nm}$, similar as to peak M (Coble, 1996), representing marine humic-like component or biological and microbial origin DOM (Shimotori et al., 2012; Yamashita et al., 2008). This component was widely found in both freshwater and marine systems (Dainard and Guéguen, 2013; Kowalczuk et al., 2009; McIntyre and Guéguen, 2013; Singh et al., 2010; Walker et al., 2009). Component $\mathrm{C} 2$ showed a maximum excitation wavelength at $<280 \mathrm{~nm}$ and emission wavelength at $330 \mathrm{~nm}$, which was similar to peak T, traditionally considered as protein-tryptophan-like component (Coble, 1996). Tryptophan-like component was linked to biological production (Coble et al., 1998) and commonly found among different aquatic systems (Dainard and Guéguen, 2013; McIntyre and Guéguen, 2013; Stedmon and Markager, 2005). Component C3 had maximum excitation wavelengths at $<270 \mathrm{~nm}$ and $365 \mathrm{~nm}$ and a maximum emission wavelength at $465 \mathrm{~nm}$. This component was comparable to peaks A and C (Coble, 1996). Despite of its terrestrial origin, similar components have been reported along a large salinity scale (Dainard and Guéguen, 2013; Kowalczuk et al., 2009; Stedmon and Markager, 2005; Walker et al., 2013).

Total fluorescence intensity $(\mathrm{TF}=\mathrm{C} 1+\mathrm{C} 2+\mathrm{C} 3)$ as well as the fluorescent component $(\mathrm{C} 1, \mathrm{C} 2$ and $\mathrm{C} 3)$ intensities (Fig. 7) were within the ranges reported earlier (Dainard and Guéguen, 2013; Guéguen et al., 2014; Walker et al., 2009). TF was relatively stable within each water mass except in ASW likely due to the influence of biological activities and sea ice melt. Maximum TF and humic-like intensities (C1 and C3) were associated with PWW (150 m; Fig. 7A-B, D), consistent with CDOM distribution (Fig. 5). Similar distributions were found in previous studies (Dainard et al., 2015; Guéguen et al., 2007, 2012b; Nakayama et al., 2011). Low TF in ASW is likely due to enhanced photobleaching (Dainard et al., 2015; Guéguen et al., 2016; Logvinova et al., 2016) associated with a greater influence of DOM-poor sea ice melt waters (Belzile et al., 2002) in surface waters. The prominent FDOM (and CDOM; Fig. 5) maximum at PWW was due to humic-rich materials brought by injection of cold saline shelf waters (Guéguen et al., 2007; Moore et al., 1983; Woodgate et al., 2005). No significant difference in humic-like fluorescence intensities was found in FSB and BSB between sites $(0.0137 \pm 0.0014$ r.u. for C1; $0.0090 \pm 0.0010$ r.u. for C3), suggesting homogeneous humic-like intensity in deeper layers. Protein-like C2 intensity maximum (Fig. 7C) was associated with the highly productive (Arrigo et al., 2008; Fouilland et al., 2007; Hill and Cota, 2005) ASW, confirming the biological origin of protein-like component. Lower C2 intensities were associated with the PSW-PWW complex and Atlantic-derived waters. Homogeneous distribution ( $p>0.05)$ was observed in AIW. 
194

195

196

197

198

Despite a $40 \%$ difference in TF (0.042 vs 0.060 r.u., p < 0.05; Fig. 8), ASW and PWW showed similar average CDOM MW values (1.37 vs $1.38 \mathrm{kDa}$ ) (Fig. 8). PWW was largely associated with the increase in aromatic CDOM (low $\mathrm{S}_{275-295}$; Fig. 5C) and humic-like FDOM (Fig. 7) due to sediment interactions (Guéguen et al., 2007; Moore et al., 1983). Although FDOM concentration and composition did not significantly influence MW in ASW and PWW, the significant decrease in MW from PWW and AIW was associated with a dramatic decrease in humic-like intensities ( $<<0.05)$. Similarly, PSW and BSB displayed comparable mean MW values $(1.27 \mathrm{kDa}$ in both water masses) but a $39 \%$ reduction $(\mathrm{p}<0.05)$ in TF in BSB. Together these results showed that a change in AF4 based MW does not necessarily mean a change in TF. This contrasts with previous studies where higher TF, and particularly higher humic-like intensities, was generally associated with higher MW material (Cuss and Guéguen, 2013; Huguet et al., 2010). Because the PARAFAC-validated components cannot be attributed to pure compounds but to a group of compounds sharing similar fluorescence properties, it is possible that a change in the concentration and/or nature of fluorescing compounds affects the fluorescence efficiency and therefore FDOM signal without changing MW. Furthermore, Stolpe et al. (2014) showed that protein-like fluorescence $(275 / 340 \mathrm{~nm})$ in marine waters had a size distribution that was very different from the size distribution of CDOM measured at $254 \mathrm{~nm}$. Further studies should be carried out to assess the influence of absorbing and fluorescing DOM composition on MW.

In terms of fluorescence composition in bulk samples (Fig. 9A-C), humic-like C1\% and C3\% decreased with increasing MW $\left(r^{2}=0.38\right.$ and 0.40 , respectively). This contrasts with protein-like C2\% which was more abundant at higher MW $\left(r^{2}=\right.$ 0.41; Fig. 9D). The change in size distribution between protein- and humic-like FDOM was also found in the northern Gulf of Mexico (Stolpe et al., 2014) where humic-like components dominated small size marine DOM while protein-like DOM was enriched in larger MW DOM. Similarly, increase in protein-like component was observed with decreasing $\mathrm{S}_{275-295}$ (i.e. increase in MW) in North Pacific seawater studies (Helms et al., 2013). Despite of variation in $S_{275-295}$, humic-like components were found to be dominant (> 50\%) throughout the study area (Dainard and Guéguen, 2013). 
For the first time, asymmetrical flow field-flow fractionation system was applied in the Arctic Ocean to assess CDOM

218 MW distribution in relation with optical properties and water masses. The CDOM MW ranged from 1.07 to $1.45 \mathrm{kDa}$, 219 consistent with earlier works. The vertical distribution of CDOM MW and optical properties showed some water-mass 220 related distribution pattern. DOM in Arctic surface waters displayed similarity in MW and fluorescence intensity across the study area. PWW formed in from ice formation and freshwater injection, showed higher MW CDOM associated with higher fluorescence intensity. Protein-like fluorescence became more dominant as MW increased, but humic-like components remained dominant throughout the water column.

\section{Acknowledgments}

The data were collected and made available by the Beaufort Gyre Exploration Program based at the Woods Hole 227 Oceanographic Institution (http://www.whoi.edu/beaufortgyre) in collaboration with researchers from Fisheries and Oceans 228 Canada at the Institute of Ocean Sciences. This work was supported by the Northern Scientific Training Program, Canada 229 Research Chair Program (CG) and National Sciences and Engineering Research Council of Canada (CG). The field program 230 on the Louis S. St-Laurent was funded by the U.S. National Science Foundation's Beaufort Gyre Observation System (PLR231 1302884) and the Department of Fisheries and Oceans Canada. We gratefully acknowledge the support of C. Wylie, S. 232 Zimmerman and W. Williams for field assistance in the JOIS cruise. We thank the captain and crew of the CCGS Louis S. 233 Saint-Laurent and the other participants of the cruise. We thank the handling editor and two anonymous reviewers for 234 helpful comments and suggestions that improved the quality of this manuscript. 


\section{References}

Amon, R. M. W., Benner, R. 1994. Rapid cycling of high-molecular-weight dissolved organic matter in the ocean, Nature, 369(6481), 549-552, doi:10.1038/369549a0.

Amon, R. M. W. and Benner, R. 1996. Bacterial utilization of different size classes of dissolved organic matter, Limnol. Oceanogr., 41(1), 41-51, doi:10.4319/lo.1996.41.1.0041.

Arrigo, K. R., van Dijken, G., Pabi, S. 2008. Impact of a shrinking Arctic ice cover on marine primary production, Geophys. Res. Lett., 35(19), doi:10.1029/2008GL035028.

Baylor, E. R., Sutcliffe Jr, W. H. 1963. Dissolved Organic Matter in Seawater as a source of Particulate Food, Limnol. Oceanogr., 8, 369-371.

Beckett, R., Jue, Z., Giddings, J. 1987 Determination of molecular weight distributions of fulvic and humic acids using flow field-flow fractionation, Environ. Sci. Technol., 21(3), 289-295, doi:10.1021/es00157a010.

Beckett, R., Wood, F. J., Dixon, D. R.1992. Size and chemical characterization of pulp and paper mill effluents by flow field-flow fractionation and resin adsorption techniques, Environ. Technol., 13(12), 1129-1140, doi:10.1080/09593339209385252.

Bélanger, S., Xie, H., Krotkov, N., Larouche, P., Vincent, W. F., Babin, M.2006. Photomineralization of terrigenous dissolved organic matter in arctic coastal waters from 1979 to 2003: Interannual variability and implications of climate change, Global Biogeochem. Cycles, 20(4), 1-13, doi:10.1029/2006GB02708.

Belzile, C., Gibson, J. A. E., Vincent, W. F., 2002. Colored dissolved organic matter and dissolved organic carbon exclusion from lake ice: Implications for irradiance transmission and carbon cycling, Limnol. Oceanogr., 47(5), 1283-1293, doi:10.4319/lo.2002.47.5.1283.

Benner, R., Pakulski, J. D., McCarthy, M., Hedges, J. I., Hatcher, P.G., 1992. Bulk chemical characteristics of dissolved organic matter in the ocean, Science, 255(5051), 1561-1564, doi:10.1126/science.255.5051.1561.

Boehme, J., Wells, M. 2006 Fluorescence variability of marine and terrestrial colloids: Examining size fractions of chromophoric dissolved organic matter in the Damariscotta River estuary, Mar. Chem., 101(1-2), 95-103, doi:10.1016/j.marchem.2006.02.001. 
Chen, Z., Li, Y., Pan, J. 2004. Distributions of colored dissolved organic matter and dissolved organic carbon in the Pearl

262

River Estuary, China, Cont. Shelf Res., 24(16), 1845-1856, doi:10.1016/j.csr.2004.06.011.

Coble, P. G. 1996. Characterization of marine and terrestrial DOM in seawater using excitation-emission matrix spectroscopy, Mar. Chem., 51(4), 325-346, doi:10.1016/0304-4203(95)00062-3.

Coble, P. G., Del Castillo, C. E., Avril, B. 1998. Distribution and optical properties of CDOM in the Arabian Sea during the 1995 Southwest Monsoon, Deep. Res. Part II, 45(10-11), 2195-2223, doi:10.1016/S0967-0645(98)00068-X.

Cole, J. J., Carpenter, S. R., Pace, M. L., Van De Bogert, M. C., Kitchell, J. L., Hodgson, J. R. 2006. Differential support of lake food webs by three types of terrestrial organic carbon, Ecol. Lett., 9(5), 558-568, doi:10.1111/j.14610248.2006.00898.x.

Cory, R. M., McKnight, D. M., Chin, Y. P., Miller, P., Jaros, C. L. 2007. Chemical characteristics of fulvic acids from Arctic surface waters: Microbial contributions and photochemical transformations, J. Geophys. Res. Biogeosciences, 112(4), doi:10.1029/2006JG000343, 2007.

Cuss, C.W., Guéguen, C. 2013. Distinguishing dissolved organic matter at its origin: Size and optical properties of leaflitter leachates. Chemosphere 92, 1483-1489.

Dainard, P. G., Guéguen, C. 2015. Distribution of PARAFAC modeled CDOM components in the North Pacific Ocean, Bering, Chukchi and Beaufort Seas, Mar. Chem., 157, 216-223, doi:10.1016/j.marchem.2013.10.007, 2013.

Dainard, P. G., Guéguen, C., McDonald, N. and Williams, W. J.: Photobleaching of fluorescent dissolved organic matter in Beaufort Sea and North Atlantic Subtropical Gyre, Mar. Chem., 177, 630-637, doi:10.1016/j.marchem.2015.10.004.

Everett, C. R., Chin, Y. P., Aiken, G. R., 1999. High-pressure size exclusion chromatography analysis of dissolved organic matter isolated by tangential-flow ultrafiltration, Limnol. Oceanogr., 44(5), 1316-1322, doi:10.4319/lo.1999.44.5.1316.

Fichot, C. G., Benner, R. 2012 The spectral slope coefficient of chromophoric dissolved organic matter (S275-295) as a tracer of terrigenous dissolved organic carbon in river-influenced ocean margins, Limnol. Oceanogr., 57(5), 1453-1466, doi:10.4319/lo.2012.57.5.1453. 
Fichot, C. G., Kaiser, K., Hooker, S. B., Amon, R. M. W., Babin, M., Bélanger, S., Walker, S. A, Benner, R., 2013. Pan-

286 287 288 289 290

Arctic distributions of continental runoff in the Arctic Ocean., Sci. Rep., 3, 1053, doi:10.1038/srep01053.

Fouilland, E., Gosselin, M., Rivkin, R. B., Vasseur, C., Mostajir, B., 2007. Nitrogen uptake by heterotrophic bacteria and phytoplankton in Arctic surface waters, J. Plankton Res., 29(4), 369-376, doi:10.1093/plankt/fbm022.

Frey, K., McClelland, J. 2009. Impacts of permafrost degradation on arctic river biogeochemistry, Hydrol. Process. 23, 169-182.

Granskog, M. A., Macdonald, R. W., Mundy, C. J., Barber, D. G. 2007. Distribution, characteristics and potential impacts of chromophoric dissolved organic matter (CDOM) in Hudson Strait and Hudson Bay, Canada, Cont. Shelf Res., 27(15), 2032-2050, doi:10.1016/j.csr.2007.05.001.

Guéguen, C., Cuss, C. W. 2011 Characterization of aquatic dissolved organic matter by asymmetrical flow field-flow fractionation coupled to UV-Visible diode array and excitation emission matrix fluorescence, J. Chromatogr. A, 1218(27), 4188-4198, doi:10.1016/j.chroma.2010.12.038.

Guéguen, C., Cuss, C.W., Chen, W. 2013. Asymmetrical flow field-flow fractionation and excitation-emission matrix spectroscopy combined with parallel factor analyses of riverine dissolved organic matter isolated by tangential flow ultrafiltration. Int. J. Environm. Anal. Chem. doi:10.1080/03067319.2013.764415.

Guéguen, C., Guo, L., Yamamoto-Kawai, M., Tanaka, N. 2007. Colored dissolved organic matter dynamics across the shelf-basin interface in the western Arctic Ocean, J. Geophys. Res. - Oceans, 112, C05038, doi:10.1029/2006JC003584,.

Guéguen, C., Granskog, M. A., McCullough, G., Barber, D. G., 2011. Characterisation of colored dissolved organic matter in Hudson Bay and Hudson strait using parallel factor analysis, J. Mar. Syst., 88(3), 423-433, doi:10.1016/j.jmarsys.2010.12.001.

Guéguen, C., Burns, D. C., McDonald, A., Ring, B. 2012a. Structural and optical characterization of dissolved organic matter from the lower Athabasca River, Canada, Chemosphere, 87(8), 932-937, doi:10.1016/j.chemosphere.2012.01.047.

Guéguen, C., McLaughlin, F. A., Carmack, E. C., Itoh, M., Narita, H., Nishino, S. 2012b. The nature of colored dissolved organic matter in the southern Canada Basin and East Siberian Sea, Deep. Res. Part II, 81-84, 102-113, doi:10.1016/j.dsr2.2011.05.004, 2012b. 
311 in the waters of the Canadian Artic Archipelago, Baffin Bay, and the Labrador Sea, J. Geophys. Res. Ocean., 119(3), 20342047, doi:10.1002/2013JC009173.

Guéguen, C., Mokhtar, M., Perroud, A., McCullough, G., Papakyriakou, T., 2016. Mixing and photoreactivity of dissolved organic matter in the Nelson/Hayes estuarine system (Hudson Bay, Canada), J. Mar. Syst., 161, 42-48, doi:10.1016/j.jmarsys.2016.05.005.

Guo, L., Santschi, P. H., 2007 Ultrafiltration and its Applications to Sampling and Characterisation of Aquatic Colloids, in Environmental Colloids and Particles: Behaviour, Separation and Characterisation, pp. 159-221.

Guo, W., Yang, L., Hong, H., Stedmon, C. A., Wang, F., Xu, J., Xie, Y. 2011. Assessing the dynamics of chromophoric dissolved organic matter in a subtropical estuary using parallel factor analysis, Mar. Chem., 124(1-4), 125-133, doi:10.1016/j.marchem.2011.01.003.

Helms, J. R., Stubbins, A., Ritchie, J. D., Minor, E. C., Kieber, D. J., Mopper, K. 2008. Absorption spectral slopes and slope ratios as indicators of molecular weight, source, and photobleaching of chromophoric dissolved organic matter, Limonology Oceanogr., 53(3), 955-969, doi:10.4319/lo.2008.53.3.0955.

Helms, J. R., Stubbins, A., Perdue, E. M., Green, N. W., Chen, H., Mopper, K. 2013. Photochemical bleaching of oceanic dissolved organic matter and its effect on absorption spectral slope and fluorescence, Mar. Chem., 155, 81-91, doi:10.1016/j.marchem.2013.05.015.

Hill, V., Cota, G., 2005. Spatial patterns of primary production on the shelf, slope and basin of the Western Arctic in 2002, Deep Sea Res II, 52(24-26), 3344-3354.

Hirose, K. 2007. Metal-organic matter interaction: Ecological roles of ligands in oceanic DOM, Appl. Geochemistry, 22(8 SPEC. ISS.), 1636-1645, doi:10.1016/j.apgeochem.

Huguet, A., Vacher, L., Saubusse, S., Etcheber, H., Abril, G., Relexans, S., Ibalot, F., Parlanti, E. 2010. New insights into the size distribution of fluorescent dissolved organic matter in estuarine waters, Org. Geochem., 41(6), 595-610, doi:10.1016/j.orggeochem.2010.02.006. 
Jiao, N., Herndl, G. J., Hansell, D. A., Benner, R., Kattner, G., Wilhelm, S. W., Kirchman, D. L., Weinbauer, M. G., Luo,

335

336

T., Chen, F., Azam, F. 2010 Microbial production of recalcitrant dissolved organic matter: long-term carbon storage in the global ocean., Nat. Rev. Microbiol., 8(8), 593-9, doi:10.1038/nrmicro2386.

Kowalczuk, P., Durako, M. J., Young, H., Kahn, A. E., Cooper, W. J., Gonsior, M. 2009. Characterization of dissolved organic matter fluorescence in the South Atlantic Bight with use of PARAFAC model: Interannual variability, Mar. Chem., 113(3-4), 182-196, doi:10.1016/j.marchem.2009.01.015.

Landry, C., Tremblay, L. 2012. Compositional differences between size classes of dissolved organic matter from freshwater and seawater revealed by an HPLC-FTIR system, Environ. Sci. Technol., 46(3), 1700-1707, doi:10.1021/es203711v.

Lawaetz, A. J., Stedmon, C. A. 2009. Fluorescence intensity calibration using the Raman scatter peak of water, Appl. Spectrosc., 63(8), 936-940, doi:10.1366/000370209788964548.

Lin, H., Chen, M., Zeng, J., Li, Q., Jia, R., Sun, X., Zheng, M., Qiu, Y. 2016. Size characteristics of chromophoric dissolved organic matter in the Chukchi Sea, J. Geophys. Res. Ocean., doi:10.1002/2016JC011771.

Logvinova, C. L., Frey, K. E., Mann, P. J., Stubbins, A., Spencer, R. G. M. 2015. Assessing the potential impacts of declining Arctic sea ice cover on the photochemical degradation of dissolved organic matter in the Chukchi and Beaufort Seas, J. Geophys. Res. G Biogeosciences, 120(11), 2326-2344, doi:10.1002/2015JG003052.Logvinova, C. L., Frey, K. E., Cooper, L. W. 2016. The Potential Role of Sea Ice Melt in the Distribution of Chromophoric Dissolved Organic Matter in the Chukchi and Beaufort Seas, Deep Sea Res. Part II Top. Stud. Oceanogr., 130, 28-42, doi:10.1016/j.dsr2.2016.04.017.

McIntyre, A. M., Guéguen, C.2013. Binding interactions of algal-derived dissolved organic matter with metal ions, Chemosphere, 90(2), 620-626, doi:10.1016/j.chemosphere.2012.08.057.

McLaughlin, F. A., Carmack, E. C., Macdonald, R. W., Melling, H., Swift, J. H., Wheeler, P. A., Sherr, B. F., Sherr, E. B. 2004. The joint roles of Pacific and Atlantic-origin waters in the Canada Basin, 1997-1998, Deep. Res. Part I Oceanogr. Res. Pap., 51(1), 107-128, doi:10.1016/j.dsr.2003.09.010.

Midorikawa, T., Tanoue, E. 1998. Molecular masses and chromophoric properties of dissolved organic ligands for copper(II) in oceanic water, Mar. Chem., 62(3-4), 219-239, doi:10.1016/S0304-4203(98)00040-1. 
360 Freezing and Shallow Circulation, J. Geophys. Res., 88(c4), 2667-2674, doi:10.1029/JC088iC04p02667,

361 Murphy, K. R., Stedmon, C. A., Waite, T. D., Ruiz, G. M. 2008. Distinguishing between terrestrial and autochthonous 362 organic matter sources in marine environments using fluorescence spectroscopy, Mar. Chem., 108(1-2), 40-58, 363 doi:10.1016/j.marchem.2007.10.003.

364 Murphy, K. R., Stedmon, C. A., Graeber, D., Bro, R. 2013. Fluorescence spectroscopy and multi-way techniques. 365 PARAFAC, Anal. Methods, 5(23), 6557, doi:10.1039/c3ay41160e.

Nakayama, Y., Fujita, S., Kuma, K., Shimada, K. 2011. Iron and humic-type fluorescent dissolved organic matter in the

Chukchi Sea and Canada Basin of the western Arctic Ocean, J. Geophys. Res., 116, 16, doi:10.1029/2010jc006779.

Nelson, N. B., Siegel, D. A., Carlson, C. A., Swan, C. M. 2010. Tracing global biogeochemical cycles and meridional overturning circulation using chromophoric dissolved organic matter, Geophys. Res. Lett., 37(3), n/a-n/a, doi:10.1029/2009GL042325.

Overland, J., Wang, M. 2013 When will the summer Arctic be nearly sea ice free?, Geophys. Res. Lett., 40, 2097-2101, $10.1002 /$ grl.50316

Pegau, W. S. , 2002. Inherent optical properties of the central Arctic surface waters, J. Geophys. Res., 107(C10), 1-7, doi:10.1029/2000JC000382.

Penru, Y., Simon, F. X., Guastalli, A. R., Esplugas, S., Llorens, J., Baig, S., 2013. Characterization of natural organic matter from Mediterranean coastal seawater, J. Wat. Supply Res. Technol., 62(1), 42-51, doi:10.2166/aqua.2013.U3.

Peterson, B., Holmes, R., McClelland, J. 2002. Increasing river discharge to the Arctic Ocean, Science, 298, 5601, 2171 2173.

De Schamphelaere, K.A.C., Vasconcelos, F. M., Tack, F. M. G., Allen, H. E., Janssen, C. R. 2004. Effect of dissolved organic matter source on acute copper toxicity to Daphnia magna., Environ. Toxicol. Chem., 23(5), 1248-1255, doi:10.1897/03-184.

Schuur, E., Vogel, J., Crummer, K., Lee, H. 2009. The effect of permafrost thaw on old carbon release and net carbon exchange from tundra, Nature 459, 556-559. 
Shi, Y. X., Mangal, V., Guéguen, C. 2016. Influence of dissolved organic matter on dissolved vanadium speciation in the

385

386 387 388 389 390 391 392 393 394 395 396 397 398 399 400 401 402 403 404 405 406 407 408 Churchill River estuary (Manitoba, Canada), Chemosphere, 154, 367-374, doi:10.1016/j.chemosphere.2016.03.124, 2016.

Shimada, K., Kamoshida, T., Itoh, M., Nishino, S., Carmack, E., McLaughlin, F., Zimmermann, S., Proshutinsky, A. 2006. Pacific Ocean inflow: Influence on catastrophic reduction of sea ice cover in the Arctic Ocean, Geophys. Res. Lett., 33(8), 3-6, doi:10.1029/2005GL025624.

Shimotori, K., Watanabe, K., Hama, T. 2012. Fluorescence characteristics of humic-like fluorescent dissolved organic matter produced by various taxa of marine bacteria, Aquat. Microb. Ecol., 65(3), 249-260, doi:10.3354/ame01552.

Singh, S., D’Sa, E. J., Swenson, E. M., 2010. Chromophoric dissolved organic matter (CDOM) variability in Barataria Basin using excitation-emission matrix (EEM) fluorescence and parallel factor analysis (PARAFAC), Sci. Total Environ., 408(16), 3211-3222, doi:10.1016/j.scitotenv.2010.03.044.

Skoog, A., Hall, P. O. J., Hulth, S., Paxéus, N., Rutgers Van Der Loeff, M., Westerlund, S. 1996. Early diagenetic production and sediment-water exchange of fluorescent dissolved organic matter in the coastal environment, Geochim. Cosmochim. Acta, 60(19), 3619-3629, doi:10.1016/0016-7037(96)83275-3.

Spencer, R. G. M., Aiken, G. R., Butler, K. D., Dornblaser, M. M., Striegl, R. G., Hernes, P. J. 2009. Utilizing chromophoric dissolved organic matter measurements to derive export and reactivity of dissolved organic carbon exported to the Arctic Ocean: A case study of the Yukon River, Alaska, Geophys. Res. Lett., 36(6), doi:10.1029/2008GL036831.

Stedmon, C. A., Bro, R. 2008. Characterizing dissolved organic matter fluorescence with parallel factor analysis: a tutorial, Limnol. Oceanogr. Methods, 6, 572-579, doi:10.4319/lom.2008.6.572.

Stedmon, C. A., Markager, S. 2005. Resolving the variability of dissolved organic matter fluorescence in a temperate estuary and its catchment using PARAFAC analysis, Limnol. Oceanogr., 50(2), 686-697, doi:10.4319/lo.2005.50.2.0686.

Stedmon, C. A., Markager, S., Bro, R. 2003. Tracing dissolved organic matter in aquatic environments using a new approach to fluorescence spectroscopy, Mar. Chem., 82(3-4), 239-254, doi:10.1016/S0304-4203(03)00072-0.

Stedmon, C. A., Amon, R. M. W., Rinehart, A. J., Walker, S. A. 2011. The supply and characteristics of colored dissolved organic matter (CDOM) in the Arctic Ocean: Pan Arctic trends and differences, Mar. Chem., 124(1-4), 108-118, doi:10.1016/j.marchem.2010.12.007. 

Arctic Ocean, J. Geophys. Res., 109(C2), 1-18, doi:10.1029/2003JC002009.

Stolpe, B., Guo, L., Shiller, A. M., Hassellöv, M. 2010. Size and composition of colloidal organic matter and trace elements in the Mississippi River, Pearl River and the northern Gulf of Mexico, as characterized by flow field-flow fractionation, Mar. Chem., 118(3-4), 119-128, doi:10.1016/j.marchem.2009.11.007.

Stolpe, B., Zhou, Z., Guo, L., Shiller, A. M. 2014. Colloidal size distribution of humic- and protein-like fluorescent organic matter in the northern Gulf of Mexico, Mar. Chem., 164, 25-37, doi:10.1016/j.marchem.2014.05.007.

Sun, L., Perdue, E. M., Meyer, J. L., Weis, J. 1997. Use of elemental composition to predict bioavailability of dissolved organic matter in a Georgia river, Limnol. Oceanogr., 42(4), 714-721, doi:10.4319/lo.1997.42.4.0714.

Tipping, E., Lofts, S., Stockdale, A. 2015. Metal speciation from stream to open ocean: modelling v. measurement, Environ. Chem., doi:10.1071/EN15111.

Tulonen, T., Salonen, K., Arvola, L. 1992. Effects of different molecular weight fractions of dissolved organic matter on the growth of bacteria, algae and protozoa from a highly humic lake, Hydrobiologia, 229(1), 239-252, doi:10.1007/BF00007003.

Walker, S. A., Amon, R. M. W., Stedmon, C. A., Duan, S., Louchouarn, P. , 2009. The use of PARAFAC modeling to trace terrestrial dissolved organic matter and fingerprint water masses in coastal Canadian Arctic surface waters, J. Geophys. Res. Biogeosciences, 114(4), doi:10.1029/2009JG000990.

Walker, S. A., Amon, R. M. W., Stedmon, C. A., 2013. Variations in high-latitude riverine fluorescent dissolved organic matter: A comparison of large Arctic rivers, J. Geophys. Res. Biogeosci., 118(4), 1689-1702, doi:10.1002/2013JG002320.

Ocean's lower halocline by upwelling and diapycnal mixing over the continental margin, Geophys. Res. Lett., 32(18), 1-5, doi:10.1029/2005GL023999.

Wu, F., Tanoue, E. 2001. Molecular mass distribution and fluorescence characteristics of dissolved organic ligands for copper(II) in Lake Biwa, Japan, Org. Geochem., 32(1), 11-20, doi:10.1016/s0146-6380(00)00155-8. 
434 stream waters by high-performance size-exclusion chromatography (HPSEC) and high-resolution inductively coupled 435 plasma mass spectrometry (ICP-MS), J. Anal. At. Spectrom., 19(8), 979, doi:10.1039/b402819h.

436 Yamashita, Y., Jaffé, R.2008. Characterizing the interactions between trace metals and dissolved organic matter using 437 excitation-emission matrix and parallel factor analysis, Environ. Sci. Technol., 42(19), 7374-7379, doi:10.1021/es801357h. 438 Yamashita, Y., Jaffé, R., Maie, N., Tanoue, E. 2008. Assessing the dynamics of dissolved organic matter (DOM) in 439 coastal environments by excitation emission matrix fluorescence and parallel factor analysis (EEM-PARAFAC), Limnol. 440 Oceanogr., 53(5), 1900-1908, doi:10.4319/lo.2008.53.5.1900. 
Figure 2: AF4 fractograms of CB29 (400m depth; black) and CB28b (1000m depth; gray)

Figure 3: A) Potential temperature and B) FDOM as a function of salinity ( $\mathrm{Sp}$ ) at the four study sites (Figure1). ASW 448 Arctic surface waters, PSW - Pacific summer water, PWW - Pacific winter water, FSB - Fram Strait Branch water, BSB 449 Barents Sea Branch water

Figure 6: Individual components identified by PARAFAC (A- marine humic-like C1, B- protein-like C2 and C- terrestrial 456 humic-like C3)

Figure 7: Depth distribution of A) Total Fluorescence Intensity (TF), B) marine humic-like C1, C) protein-like C2 and D) 459 terrestrial humic-like C3 


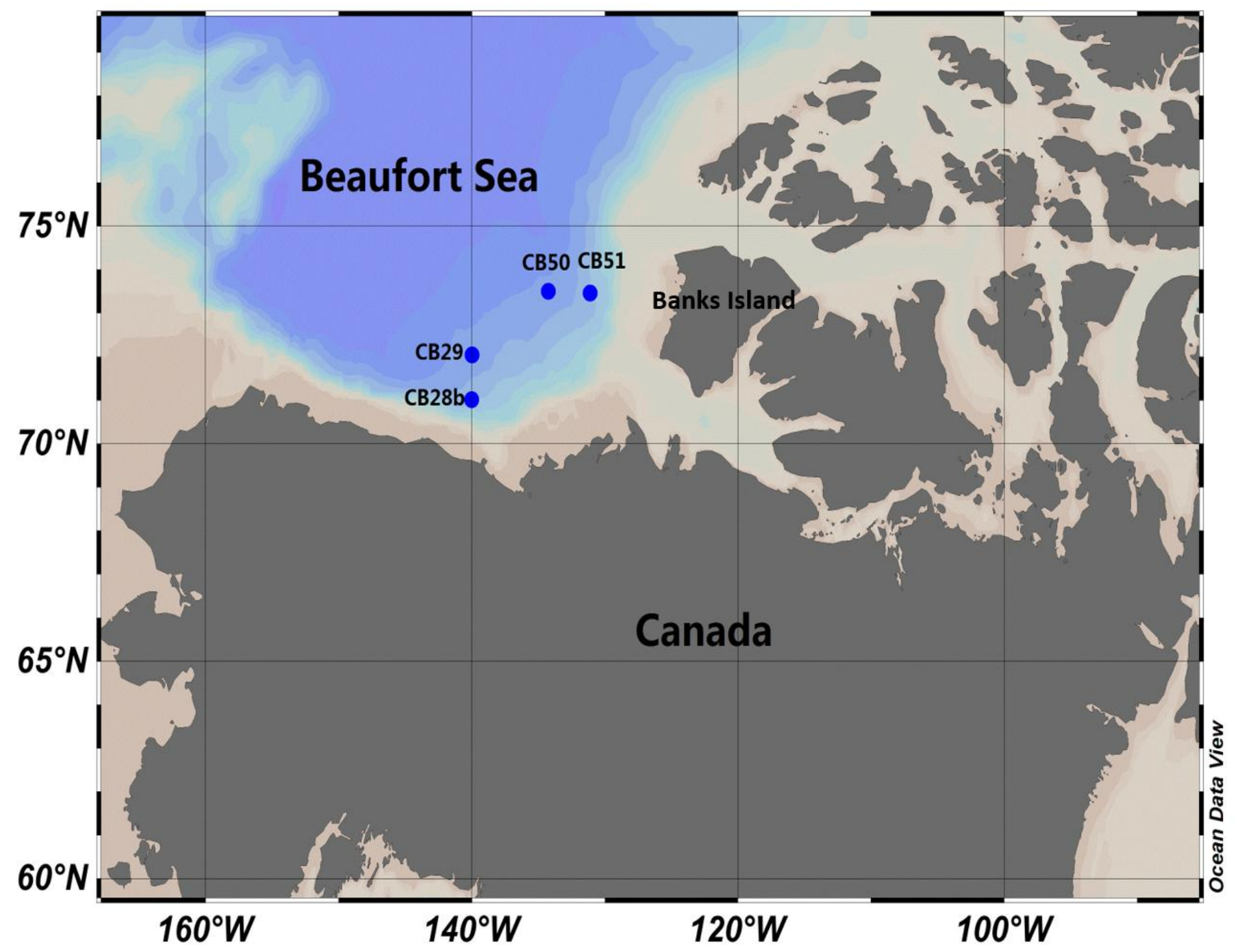




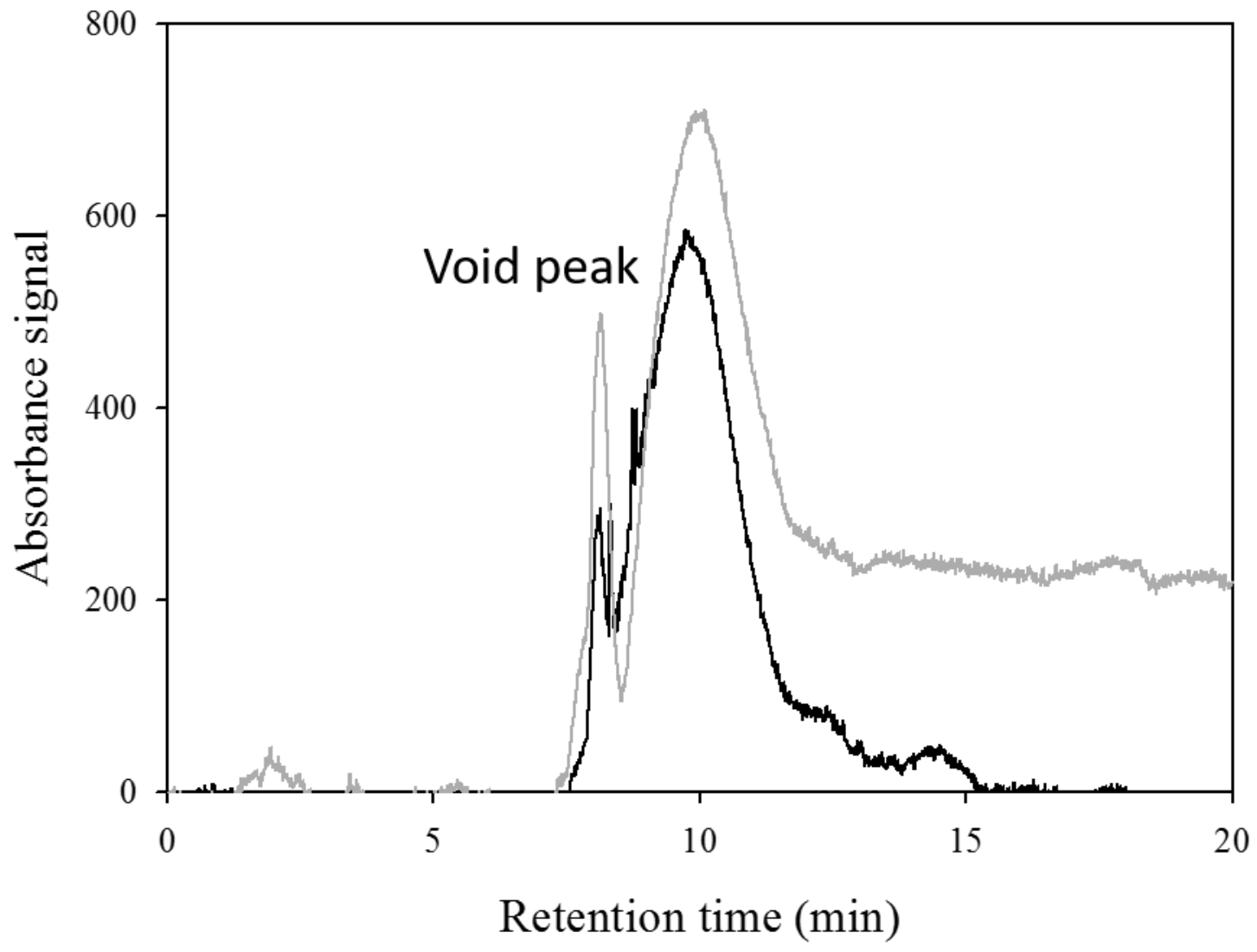

Fig02 

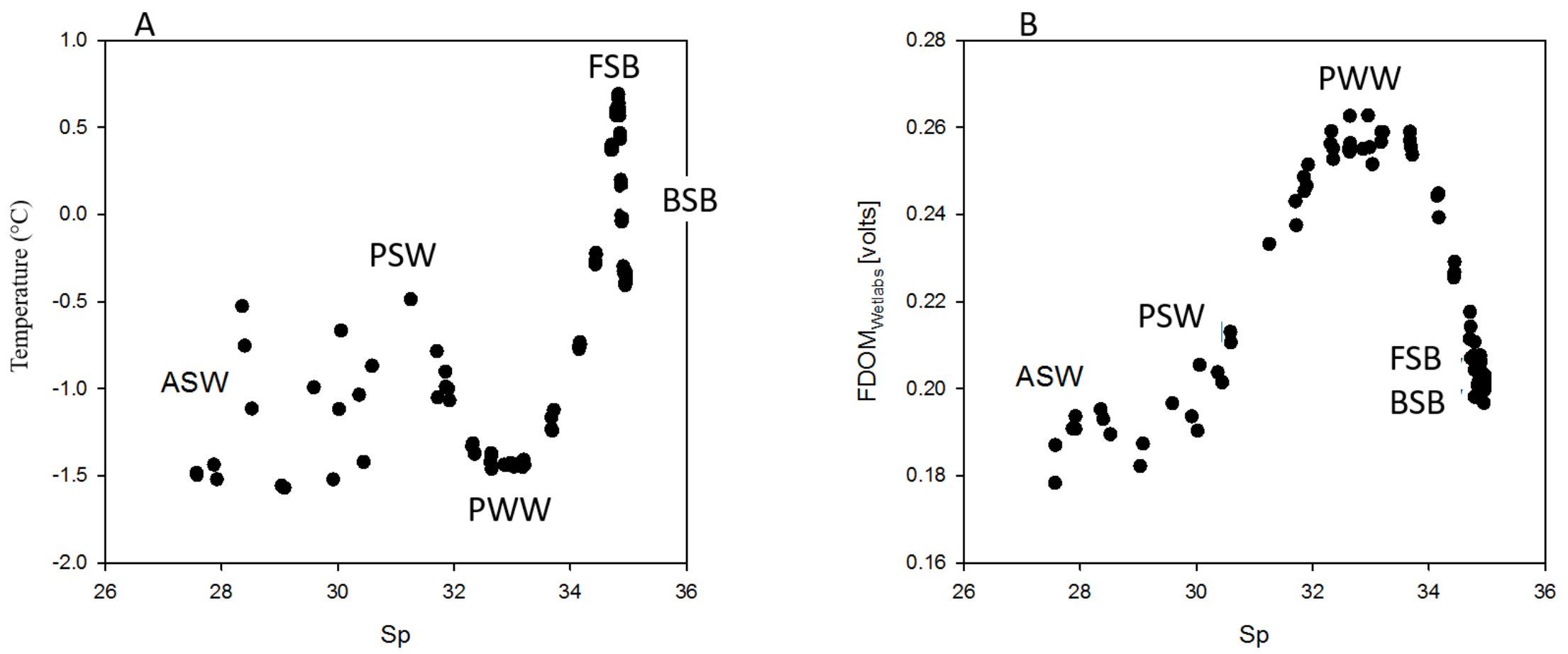

Fig03 


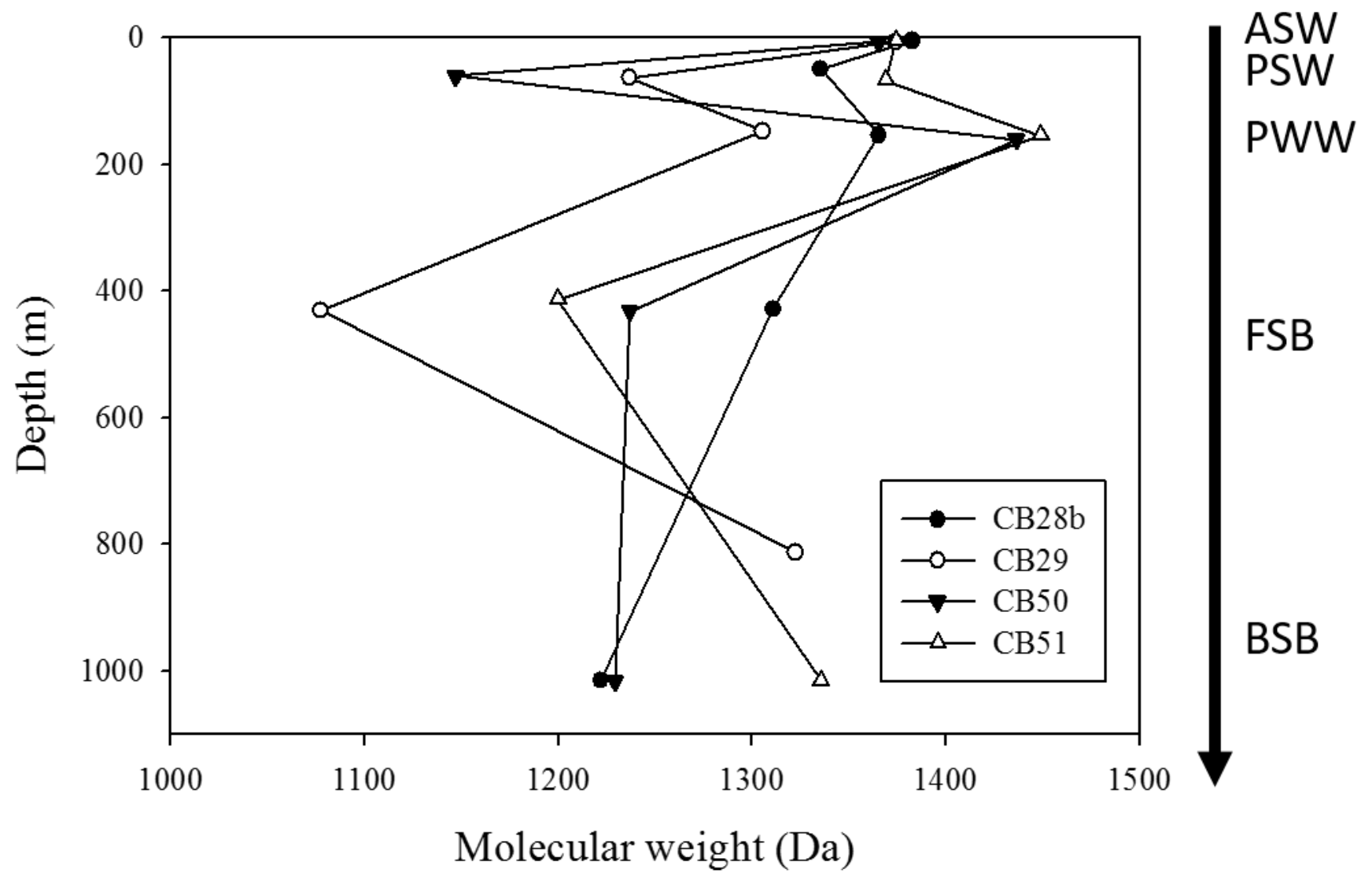

Fig04 

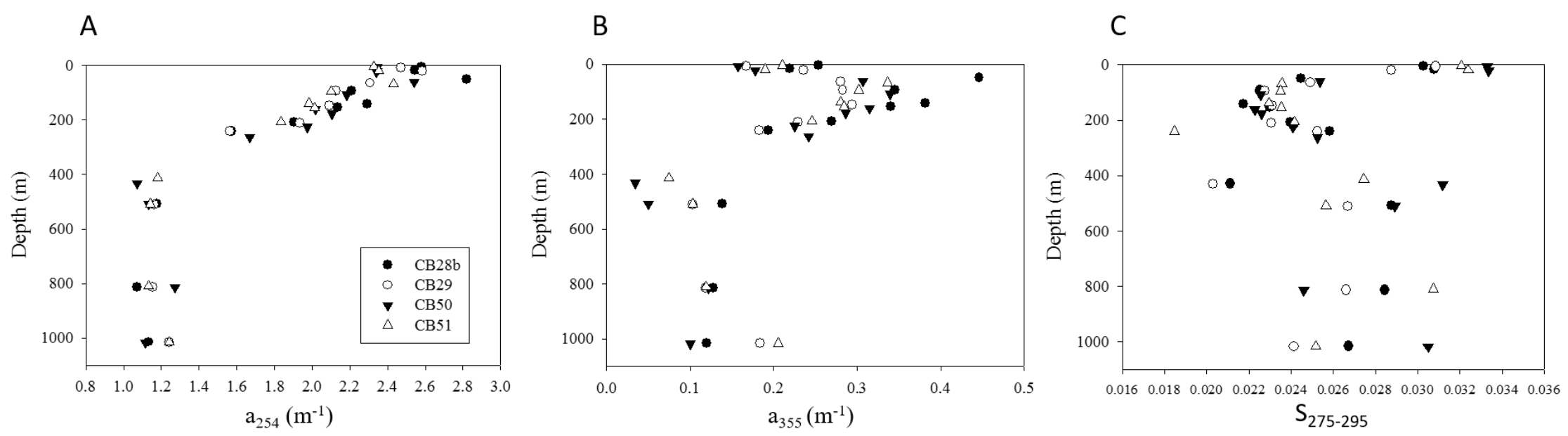

Fig05 

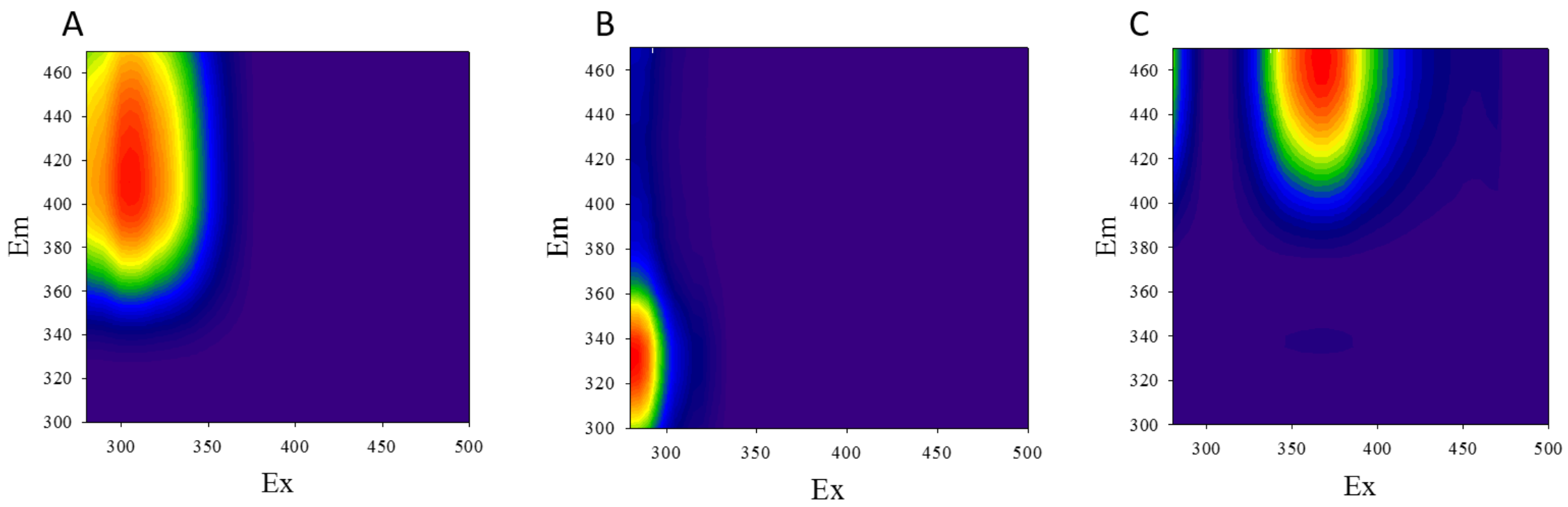

Fig06 

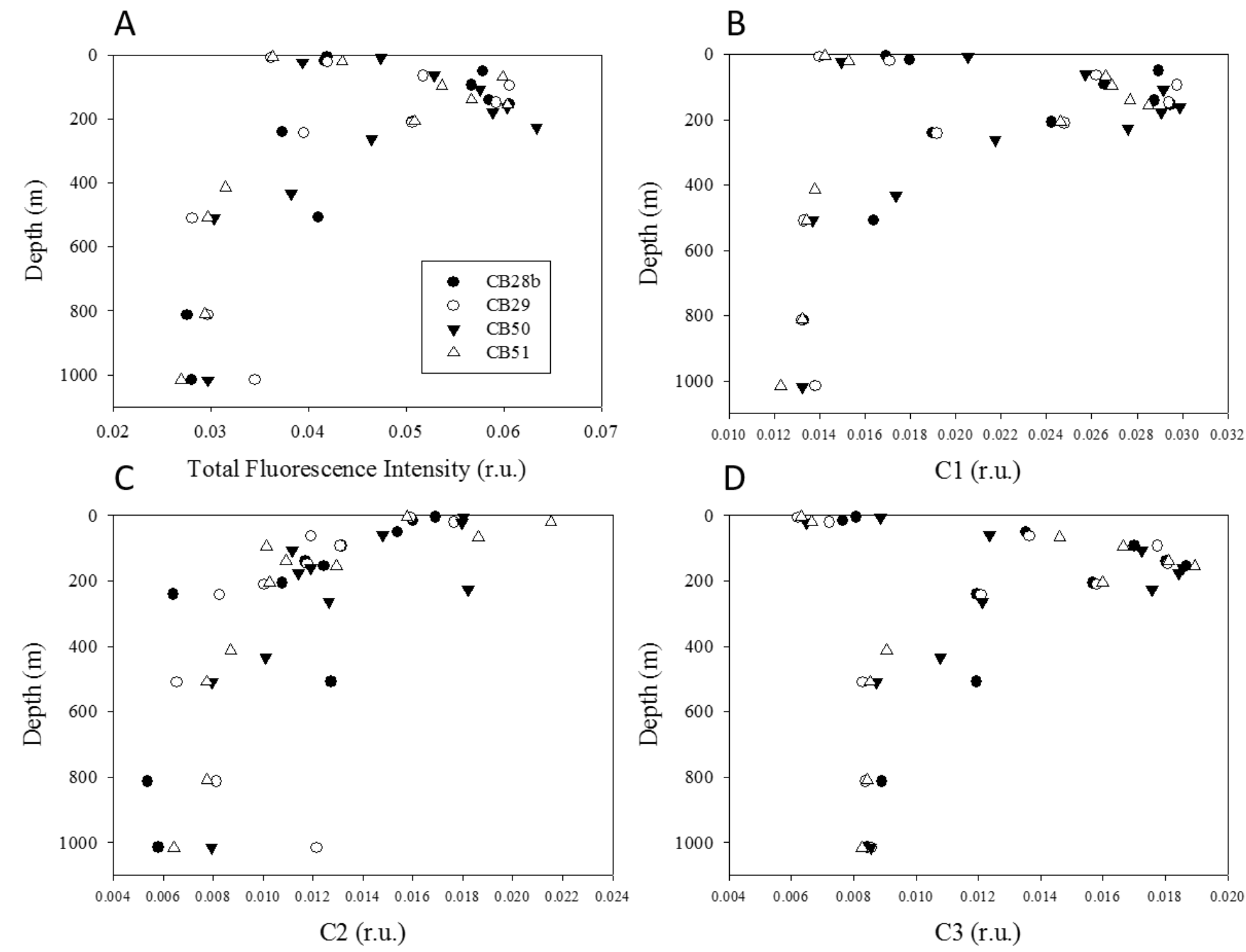

Fig07 


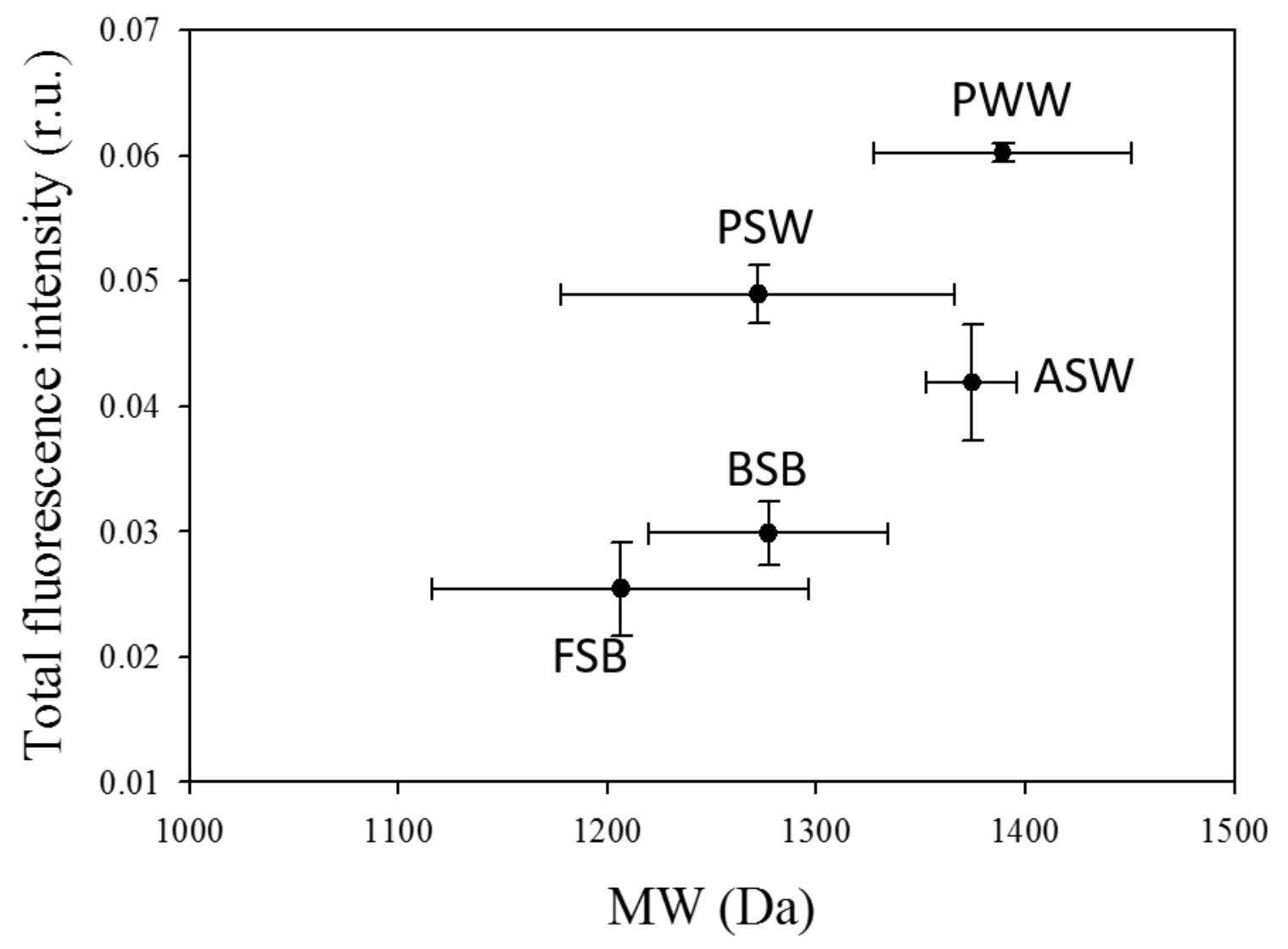

Fig08 

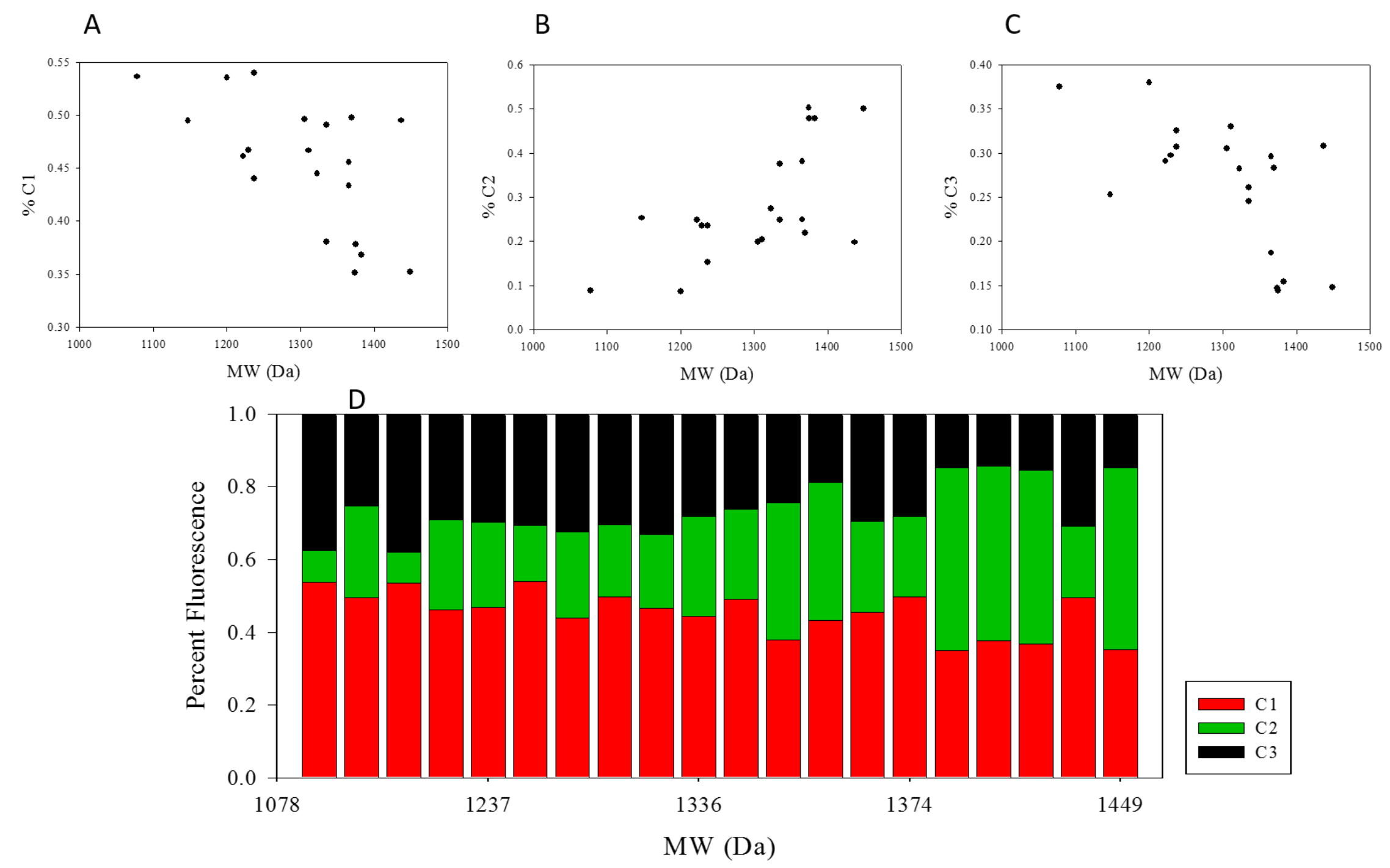